Article

\title{
Decolonizing People, Place and Country: Nurturing Resilience across Time and Space
}

\author{
Richard Howitt \\ Department of Human Geography, Macquarie University, Sydney, NSW 2109, Australia; \\ richie.howitt@mq.edu.au
}

Received: 9 June 2020; Accepted: 9 July 2020; Published: 22 July 2020

check for updates

\begin{abstract}
Indigenous peoples are easily classified as either dangerously vulnerable or inherently resilient to climate risks. There are elements of truth in both categorical statements. Yet neither is completely true. Indigenous vulnerability and resilience, and Indigenous groups' adaptive responses to climate change, need to be understood in the messy contexts of lived experience, rather than either elegant social theories or didactic ideological politics. Climate change action and research needs to acknowledge and engage with the knowledges, ontologies and experiences of diverse Indigenous groups, along with the specific histories, geographies and impacts of colonization, and their consequences for both the colonized and colonizers. Climate change action and research needs to be integrated into wider de-colonial projects as the transformative impacts of anthropogenic climate change are inadequately addressed within both colonial and post-colonial frames. Negotiating respectful modes of belonging-together-in-Country to reshape people-to-people, people-to-environment and people-to-cosmos relationships in Indigenous domains is essential in responding to planetary scale changes in coupled human and natural systems. This paper outlines an approach that nurtures Indigenous self-determination and inter-generational healing to rethink the geopolitics of Indigenous resilience, vulnerability and adaptation in an era of climate change and the resurgence of Great Power geopolitics.
\end{abstract}

Keywords: climate change; country; coupled human and natural systems; Decoloniality; geographical scale; indigenous peoples; ontological pluralism; ontological and existential risk; social and environmental justice

\section{Acknowledging}

So much begins with acknowledging. Where denial narrates absence, silence and closure, acknowledging opens possibilities. Acknowledging invites relationships, engagement and connection. It challenges difference and invites conversation. In our era of denial—of climate change, human rights, identity, connectedness and mutual dependence-acknowledging is important. Acknowledging Indigenous peoples' rights and the rapid environmental changes currently occurring across multiple places, multiple scales, and multiple species and systems opens opportunities for learning, collaborating, understanding and surviving across boundaries of difference.

Dharug Nura is the place now known as Greater Sydney, on the east coast of the southern continent. I was born and have lived and worked in this Country for most of my life. It was, and remains, the traditional Country [1] of the Dharug-speaking clans who faced the first waves of British settler colonialism on the southern continent of Australia in the late 18th Century. In Dharug Nura, it was always customary for guests and visitors to wait to be welcomed by the people of that Country, and to acknowledge the Country and its people, places and stories. In the customary law of many of the First Nations of the southern continent, the Welcome to Country not only introduces a visitor to the current inhabitants (human and non-human) of a place to offer recognition and protection. The 
Welcome also invites the guest to recognize their own obligations towards the Country and its people, and its inhabitants and its pasts, presents and futures.

\section{Warami Wellamabami Didjergura Ngara}

This is the acknowledgement that I used when presenting this paper to the conference that inspired this collection of papers. Welcome wherever you are from. Thank you for listening. This greeting in the Dharug language, recognized the commonality between myself as a speaker and the listeners in my audience. Unlike the ethical presence of spoken delivery to an audience, however, distillation in print delays or even avoids conversational engagement, where ideas might be contested, responded to, refined and revised. The immediacy of the face-to-face relationship of speaker and audience creates both invitation and challenge. Presenting the paper as text renders our relationship as detached writer-and-reader, rather than as listeners-to-each-other sharing time-and-place. It separates us from each other in time and place-even though we share both time (Anthropocene) and place (Earth).

As a geographer, I have spent several decades grappling with relational concepts of time-space, place and scale. Let me stretch across time, place and scale to open my invitation and challenge to you by acknowledging Dharug Nura and Dharug yura, the Country and Ancestors of the First People of the Wallumattagul clan, the Wullamai black snapper fish people, of the Dharug Nation. I pay respect to their Elders past, present, emerging and future, the wisdom and knowledge passed down through their generations, and the Dharug knowledge being generated in the present. I also acknowledge the Indigenous peoples of the places where many of you are reading this paper, and the Indigenous peoples of Taiwan, where many of these ideas were discussed and debated in the conference that gave rise to this special issue of Sustainability.

\section{Reconsidering Indigenous Vulnerability and Resilience in Climate Risk Discourses}

Contemporary academic discourse addresses both the nature of anthropogenic climate change and the risks it poses to particular people, places and human systems, and the natural systems to which we are all coupled in complex ways. Two important discursive threads invoke the concerns of Indigenous peoples. One emphasizes vulnerability, arguing that Indigenous groups are particularly vulnerable to climate risks-often because of their indigeneity [2]. The other thread emphasizes Indigenous peoples' exceptional adaptive capacity as being relevant to framing responses to climate change [3,4]. Indeed, it often argues that Indigenous resilience will produce solutions to the problems created by anthropogenic climate change.

Both these discursive modes frame Indigenous dimensions of climate risks, suggesting that Indigenous societies in general have either particular weaknesses or particular strengths that are exposed by climate change. While both offer insights into conditions facing particular Indigenous groups, they both risk stereotyping, oversimplifying and marginalizing the diverse experiences, insights, understandings and lessons that might be generated by engaging with Indigenous peoples.

Like all generalizations, each of these discursive threads reflects some truth. But neither is always nor completely true. Context matters in how we think about the intersection of Indigenous geographies and histories with the realities, discourses and policy responses to anthropogenic climate change. Ostrom [5] acknowledged that there are no easy solutions to problems in coupled human-natural systems: no panaceas. There is "no simple way of representing, understanding or responding to the complexity in settings that are simultaneously biophysical and cultural" [6] (p. 2). Nor are the diverse cultures and experiences of Indigenous groups reducible to some sort of Indigenous-singular that reflects a distinctive and common approach to being human.

Drawing on philosophical traditions of radical contextualism [7], this paper suggests the context of climate change needs to be better understood as involving multiple scale frames (both spatial and temporal) of alienation and belonging. Policy, science and practice all need to develop a much more sophisticated literacy in the scale politics of responding to the risk landscapes that Indigenous groups negotiate. 
We have to learn to think anew - to think in ways that take seriously and actually respond to information, understanding and knowledges as if difference confronts us with the possibility of thinking differently [6] (p. 4).

\section{Procedural Vulnerability}

Veland suggests that procedural vulnerability amplifies the risks many Indigenous groups face from anthropogenic climate change [8,9]. State agencies easily assume (or perhaps hope) that their administrative procedures will adequately address the needs of all their citizens. It might be more accurate to say that the settler-colonial state assumes that all its citizens should conform to the requirements of the state. In settler-colonial societies, histories of racism, misunderstanding and greed mean that that many state procedures and the policies that support them fail to recognize, acknowledge, or respond to realities that affect Indigenous peoples within their jurisdictions. Structural racism, historic injustices, dispossession, violence and the normal features of colonial contexts create very different risk landscapes for Indigenous peoples. Even well-intentioned actions reinforce and produce vulnerability [2,10-13].

Drawing largely on experience from Australia, this paper concludes that Indigenous vulnerability, resilience and adaptive responses need to be understood and engaged with in relation to the messy contexts of lived experience in settler-colonial societies, rather than either elegant social theories or didactic ideological politics. The diverse knowledges, ontologies and experiences of different Indigenous groups, along with the particular (scaled) geographies and histories of colonization, and their impacts on and consequences for both colonized and colonizers, need to be taken seriously-discussed, debated and considered carefully, rather than simply treasured or ignored. Climate change researchers need to take them seriously and engage with the histories, geographies and current processes of colonization affecting Indigenous groups as Indigenous groups themselves consider (and renegotiate) the risk landscapes that are woven around them by climate risk and policies, procedures and practices of disaster risk reduction. Scholars need to include Indigenous groups as part of their critical audience.

\section{Anthropogenic Climate Change Is a Colonial Legacy}

Anthropogenic climate change is a colonial legacy that is having transformative impacts on the coupled human-and-natural systems on which survival depends. Neither colonial nor conventional post-colonial frames that leave the deep colonizing of Indigenous domains unrecognized, unacknowledged and unchallenged will allow actions to address those impacts safely and sustainably.

In the southern summer of 2019-2020, even prior to the impacts of the Covid-19 pandemic, Australia experienced a series of ecological tragedies. For example:

- In Australia's largest inland river system, the Murray-Darling Basin, prolonged drought contributed to mass fish kills [14-16].

- Extensive wildfires in an extended fire season raged across Eastern, Southern and Western Australia, bringing death and destruction, including the destruction of the small rural primary school at Wytaliba-a school which I helped to establish in 1984 [17-20].

- Massive dust storms moved topsoil from inland areas of the continent affected by prolonged drought [21].

- $\quad$ Extreme storm events left large areas of Sydney blacked-out and flooded for many days, and wreaked havoc on coastal areas with high tides, coastal flooding and huge swells [22,23].

There was a chorus of inaction and denials from the national government that such events were linked in any way to anthropogenic climate change $[19,24,25]$. The subsequent emergence of the Covid-19 pandemic and its social and economic implications have further diffused the public debate of failing policies on climate, energy and environment as economic growth is again prioritized over environmental and social sustainability by neoliberal forces. 
In responding to the unprecedented drought which threatens the water supply and continuing economic activity in multiple communities across Australia's Murray-Darling Basin, for example, governments have ordered scientists to relocate fish from the river to 'save' them. The market solutions entrenched by intergovernmental agreements, which have seen rich investors buy water rights to create profit, and zero allocation of water to the Barkindji people, whose native title rights to land in the basin were recognized in 2015 after 18 years of legal struggle [26], are under review. But the overallocation of water persists. Marketization has not resolved failed relationships within and between communities, their water sources and their economic viability under changing environmental conditions. This should, perhaps, come as no surprise $[27,28]$. But it certainly comes at a high social and environmental cost [21,29].

As communities are disconnected from reliable water supply, they fragment and dis-integrate. Some people leave, while the remaining groups and individuals compete for dwindling resources. People look for both saviors and scapegoats-and become depressed when neither can be found. In places where the scars of colonial racism run deep, these communities have never really shared common ground. They see the place they share differently. The deep understanding of environmental change embedded in Indigenous Australian cultures, and their resilience in adapting to change, in surviving, in remaining present, has rarely been acknowledged by the systems that colonization imposed to produce wealth for the settler-colonial society and its imperial (and, later, state and national) governments.

Historically, settler-colonial systems operated as if the erasure of Indigenous peoples from the physical landscape could secure colonial property systems and the wealth they would produce [30]. Contemporary market failures and the exhaustion of ecosystems, such as is occurring in inland Australia, underpins (yet another) phase of failure of colonization. Inland Australian landscapes were long misunderstood by their ambitious colonizers [31-34]. As elsewhere, Australia's European colonizers assumed that their arrival (and even their anticipated arrival—for example, in South Australia, the Crown sought to argue that native title in that state was extinguished two years before any colonial occupation by actions of the British Colonial Office in London [35]) marked the beginning of history [36], and gave them a right to possess places and dispossess (and annihilate) their peoples. They assumed that their presence superseded any existing system of governance in the ancient jurisdictions and gave them unchallenged ownership of the resources created in other times, such as underground water and energy resources.

The settlers, and the governments that created them, told stories that asserted that their hard work and sacrifice, and the risks they took in travelling so far into places that were unknown (to them), gave them a God-given, and therefore unchallengeable, right to possess, to exploit, to do as they wished. Wolfe reflected that:

settlers generally have a lot to say about work, sacrifice, and earning things the hard way. The refrain is familiar, the implication constant: We deserve what we have-or, more pointedly: We have a right to this land... As the settler takes over the territory, so does the territory take over the settler-hence the distinctive vascular condition of having the land run in one's blood. Land is settler colonialism's irreducible essence in ways that go well beyond real estate. Its seizure is not merely a change of ownership but a genesis, the onset of a whole new way of being-for both parties. Settlers are not born. They are made in the dispossessing, a ceaseless obligation that has to be maintained across the generations if the Natives are not to come back. [37] (p. 1)

Therefore, let me ask this question: what is revealed when the monumental failure of colonial stewardship, responsibility and care in Australia is laid bare by such dramatic crises at the whole-of-landscape scale? If the genesis it underpins has failed, what is left? Such failure reveals the uncivilized, primitive, barbaric and ignorant actions perpetrated by settlers upon both the people and Country of First Nations in the name of civilization (and in the service of self-interest). Those actions, those original denials, laid foundations of failures that others continue to amplify into the present. Those empowered by Australia's colonizing systems refused to understand, value and protect fundamental connections between human and natural systems, between societies and environments, 
and between people and their places. They promulgated that failure as something to be admired, celebrated and continued when they advocated Australia's right (indeed necessity and even obligation) to maintain its fossil-fueled economic occupation of the southern continent in international climate change negotiations.

As the theme of this special issue suggests, the economic models of colonialism were always based on crossing spatial boundaries and collapsing temporal boundaries. But they did so without understanding the relationships that were threatened, or the forces being unleashed. The assumption underlying those models was that growth without limits (or at least systems in which the growth of wealth for some seemed to have no limits) was both desirable and possible. That was simply normal. Growth could be fostered by crossing spatial boundaries to continuously consume the resources of other people's places, other people's livelihoods. It could be fostered by collapsing space-time to convert the energy of bygone ages into political power over places and their populations, and into a future that sought to preclude any alternatives.

As growth was measured and celebrated, and as wealth was distributed to the deserving rich, it seemed that the pauperization of local populations and the degradation of their landscapes could be modelled and treated as an externality that did not affect the logic or resilience of the colonizers' systems. After all, under the conditions created by settler colonialism, environmental capital in general—and land, water, timber, minerals, and fossil fuels in particular-were free and effectively unlimited. They became the property of the sovereign settler-colonial states.

Australia's 18th Century European colonizers assumed that the customary owners of the diverse landscapes of the southern continent were simply too 'primitive' to be accorded rights or recognition. In the landscapes the colonizers coveted, they saw the bounty of nature (which was theirs to take) rather than the product of Aboriginal Australians' careful management and their civilizations' nurturing of the continuing connection between people, place and cosmos $[38,39]$.

However, the Australian civilizations that were violently displaced by European colonialism were amongst the first human cultures to develop agriculture, baking and aquaculture. They were violated along with the landscape [38]. The colonizers dismissed those ancient jurisdictions and institutions as primitive and without law, culture, or civilization. The civilizations of the southern continent reflect some 65,000 years of human experience, thinking and adaptation [40] connected by continuing culture. They offer profound examples of what connecting-to and belonging-to place means in the context of large-scale environmental change.

What was achieved in those ancient jurisdictions was, in Gammage's words, a "majestic achievement":

only in Australia did a mobile people organise a continent with such precision ... They sanctioned key principles: think long term; leave the world as it is; think globally, act locally; ally with fire; control population. They were active, not passive, striving for balance and continuity to make all life abundant, convenient and predictable. They put the mark of humanity firmly on every place. They kept the faith. The land lived... This was possession in its most fundamental sense. If terra nullius exists anywhere in our country, it was made by the Europeans. [39] (p. 323)

The profound failure of settler-colonial stewardship on the southern continent fundamentally reflects the same economic and geopolitical forces that are the drivers of anthropogenic climate change. The greed of imperial kleptocrats might have been replaced by global entrepreneurs whose unimaginable wealth has been so powerfully criticized in the efforts to address the climate emergency [41,42], but the risks imposed on Indigenous groups have remained and been amplified.

\section{Rethinking the Scale Frame of Risk Landscapes}

There is extraordinary complexity in the contemporary risk landscapes that are affected by anthropogenic climate change. There is also extraordinary complexity in the contemporary risk landscapes negotiated by Indigenous groups whose right to exist, to retain language, culture and a 
place in contemporary space and time is so profoundly challenged by the logic of settler-colonialism. It is important to recognize that vulnerability and resilience sit side by side in those risk landscapes, and that strategies to respond and adapt to changing circumstances are never simply technical.

Climate risks (along with disaster risks, health risks, and broader societal, environmental and political risks), and responses to them are experienced, reconsidered and enacted in locally contingent landscapes. Climate injustice is just one element of the broader context of injustice constructing the risk landscapes many Indigenous groups negotiate in their everyday lives. Current circumstances in Indigenous Australia reflect histories of dispossession, denial and erasure [43]. The unfolding climate emergency challenges not only our understanding of our shared place in rapidly changing social, economic and political circumstances, but also in planetary scale systems. In particular places, the climate emergency unfolds as much as a crisis of belonging as a crisis of survival. At the planetary scale, any sense of belonging-together-in-place which underpins the possibility of common risk and common futures is constantly threatened by the economics, politics, and philosophies of competition, privilege and entitlement in globalizing human systems.

Dominant academic and political discourses frame the risks of climate change as pre-eminently global. That is, those discourses frame the most urgent risk landscape as being embedded in a singular global system whose complexity requires world-class experts to be privileged in decision-making. Technological optimists fantasize geo-engineering solutions at global and even greater-than-global scales $[44,45]$, and the politics of negotiation affirm the primacy of nation states in producing solutions (see e.g., [46,47]). Even the most recalcitrant state actors are given more influence than even the wisest non-state Indigenous actors (see e.g., [47]).

Crisis narratives encompass the ecological, financial, political and climatic dimensions of coupled human and natural systems. Human societies (and those with whom we share the planet) face once-unimaginable risks, but in framing these as 'global', they risk being disconnected from the scales of conventional human sociality. Human societies approach thresholds for apocalyptic failure in planetary scale systems that are crucial to survival [48]. Our survival and prosperity are complexly dependent on these coupled human and natural systems that are on the brink of irreversible and consequential change. In these new global risk landscapes, crisis narratives offer glimpses of the possibility of an ending of the world. New technologies extend (or collapse) time horizons. New globalized spatial links shift the cumulative impacts of changing human-human and human-nature relationships, and combine them in ways that threaten multiple extinctions and even human and planetary survival. But narratives of growth and progress have been so naturalized and normalized that they obscure the lived experiences of Indigenous peoples. Even the crime of genocide and the wickedness of ecocide have been made invisible.

While the global disaster narratives reflect important truths, the everyday landscapes of risk continue to reflect the mundane issues of disease, poverty, food security, violence and marginalization of particular groups of people in specific places. The Covid-19 crisis has reminded us that there is always a risk that these everyday risks will intrude into global geopolitics. This is not to evoke the site-focused or flattened ontology advocated by Marston and her colleagues [49]. Rather, it is a call to recognize that the places and systems drawn into our contemporary risk landscapes are always scaled—spatially and temporally. The time horizons of everyday risks are often framed in terms of much shorter-term survival from day-to-day and week-to-week, rather than in terms of epochal shifts to an Anthropocene [50]. It is in these everyday risk landscapes that Indigenous peoples' vulnerabilities and resilience are generally performed. Despite the plethora of threats and repeated predictions of their imminent demise in many places across the world, Indigenous Peoples survive, adapt and persist. Their survival challenges colonizing narratives of their extinction, disappearance, absorption, inferiority, or irrelevance. The celebration of survival should not, of course, diminish the risks and very real violence experienced by Indigenous peoples in specific places under various forms of colonial governance. Nor can the need to recognize and address the genocide, inhumanity and criminality in the relations between various state and corporate actors and Indigenous groups be avoided or delayed. 
In considering the narratives of impending catastrophe, however, it is worth acknowledging that Indigenous survival speaks loudly to narratives of sustained resilience, survival, adaptation and responsiveness.

\section{Ontological Risk as Context}

Many contemporary risks are unprecedented, and were quite literally unimaginable in earlier settings [51]. The scales at which they are constructed and performed reshapes the lived landscapes of risk in ways that undermine people's (and peoples') capacity to recover from and adapt to disaster events. They need to be understood as ontological risks because they put at risk the foundations of the possibility of existence. Human experience is not simply 'existence' or 'being' (as conceptualized, e.g., by Heidegger [52]), nor even 'being-together' (as discussed by, e.g., Nancy [53]), but 'belonging-together-in-place' e.g., [54]. Those things that threaten our environmental and social relations, and the human and natural systems within which become part of human societies, constitute ontological risks. In the Anthropocene, whole societies face ontological risks-situations which undermine people's understanding of the cosmos and their place within it. These are risks that create uncertainty at an ontological level. The previously unthinkable, unspeakable and unknowable becomes entrenched in the landscapes and relationships of everyday risk. As part of this, many Indigenous societies face the challenge of adapting and responding whilst being surrounded by hostile settler societies and confronted by state programs intended to erase their ways of life and being. This is the continuing unnatural disaster of colonization in everyday lives [13].

The dominant discourses of science, governance and power have assumed the validity of their own claims to universal and singular truth in defiance of the realities of ontological pluralism in contemporary coupled human and natural systems [7,55-57]. Following the insights of Stoffle and his colleagues [58-61], Anthropocene discourses must confront human systems with previously unimaginable risks. Those elements which form the building blocks of human society and provide the ontological certainties of existence have become uncertain and at risk. A previously unimaginable ending of the world (see also, e.g., [62]) must become a topic of common discourse.

In disaster studies, attention is given to the cycle of preparation, risk reduction, emergency response, recovery, reconstruction and further preparation [63-68]. Yet these expert-centered discourses are often deaf and blind to the nuances of local, non-technical knowledges and experiences. Sustainability science [69] and post-developmentalism [70,71] offer some valuable critiques of the dominant conversations. But Indigenous critique, which often foregrounds issues of the profound insight of local knowledges, understanding and values [6,72], offers an important additional element of challenge. There is a scale politics at work in this critique. Indigenous discourses are not simply 'local', but often articulate a connectedness that insists on holding global systems of economic, environmental and political governance accountable. There is an important sense in which they give the local ontological priority in ways that currently-dominant global discourses, including the Anthropocene narratives, seem to have trouble in conceptualizing.

\section{Narrating Risk and Power}

In the dominant expert narratives, the acceleration towards tipping points in multiple planetary scale systems [73] (see also e.g., [74,75]) reinforces the idea that only those with global expertise should be empowered to act decisively. As Veland and Lynch put it, the stories we tell ourselves matter. Dominant storylines about climate change and risks "rest on the assumption that there can be a unified grand narrative of human-environment relations ... [but this] unwittingly constrains the solutions we are prepared to admit" [76] (p. 4).

They note that these linear narratives also reinforce the colonial narration of "linear and authoritarian histories" and imply (or perhaps simply assume) that only interventions that conform and respond to the linear narratives of progress will shift the narrative and the outcome. Furthermore, as Liverman puts it, such narratives also "tend to obscure the historical geographies of anthropogenic 
climate change and have fostered solutions that are often unequal and somewhat ineffective in reducing the risks" [47] (p. 280).

Even where it is contested by climate change denial, many of the narratives built on the assumption that history follows a linear trajectory focus on market-based solutions and the attractive opportunities for investment in those solutions as avenues for continued growth [77]. Yet such storylines often ignore (or deliberately bury) historic and continuing environmental injustices that are just as central to the narrative and its outcomes as the stories of success, wealth and privilege. They silence the environmental and social implications of market failures. Indeed, the inter-national system's ongoing reluctance to provide a legal framework that would provide justice—or even recognition—for environmental refugees reinforces the colonial thrust of contemporary geopolitics. It has hard to see how conventional geopolitical processes addressing climate change will be able to "stop the proliferation of dangers for indigenous peoples ... Environmental injustices aren't any less likely in actions taken in the spirit of urgency to adapt to climate change and mitigate a $2{ }^{\circ} \mathrm{C}$ rise" [78] (p. 2).

Whyte suggests there is a paradox underpinning much of the discussion about Indigenous people and climate risks:

Consent, trust, accountability, and reciprocity are qualities of relationships that are critical for justice-oriented coordination across societal institutions on any urgent matter. Yet they are precisely the kinds of qualities of relationships that take time to nurture and develop. That is, they are necessary for taking urgent action that is just, but they cannot be established urgently. [78] (p. 2)

\section{Scaling Time and Space in Risk Landscapes}

Reconceptualizing the narratives of climate risk as a multiplicity of disconnected or singular local narratives is no panacea for tackling the difficult conversations of extinction, catastrophe and adaptation. A shift in how scale is used as a lens on these issues may, however, help to bring new things into clearer focus. Leaving the scale of catastrophe at the global, seeing it solely in terms of global governance mechanisms and intergovernmental treaties, tribunals and action plans leaves the risks as literally unimaginable for many people and communities. For those whose faith is focused on technological fixes, narratives such as the idea of a "good Anthropocene" [79] promise new ways of delivering energy, new ways of transporting goods and people, and new solutions to the risk of annihilation through large scale projects of global cooperation in geo-engineering [80] or global governance [81,82].

Of course, the scale politics of genocide, ecocide and catastrophe always play out between the local and the global, the past and the future and, as Dalby notes, the good, the bad and the ugly [83]. The global is always local (and vice versa). The interdependence of human and natural systems means that wholly isolated local or solely global systems do not exist in the Anthropocene. Shifting thinking about the scales at which risk is embodied to recognize that the landscapes of risk are always simultaneously biophysical and cultural demands the recognition that the ways in which key relationships (ecological, geopolitical, economic) are scaled demands a shift in thinking that moves the focus from indicators to relationships. That shift also demands a shift in our thinking about temporal scales to encompass inter-generational trauma and responsibility [84].

Confronted with the recognition of unimagined risks, ongoing unnatural disasters and ontological and existential apocalypse, Indigenous peoples' experiences of rapid, catastrophic transformation in coupled human and natural systems at the scale of their known worlds offers a powerful experiential window on how to address the possible ending of the world. For too long, the long and terrible shadow [85] of the linear narratives of settler-colonial conquest that underwrite the superiority and inevitability of imperial power and corporate ascendancy have muted-and even silenced-more modest narratives of connection, belonging and accountability.

In offering some brief windows on Indigenous experience, my intention is not to be exhaustive or encyclopaedic, but to evoke an understanding of both the tragic history and the remarkable resilience of many First Nations around the world. There is no simply positive or naively optimistic story to be 
told here, but there are some important pointers to what is possible-and what transformation might be possible-if we accept that climate change is a legacy of colonialism and injustice that extends well beyond the focus on climate debates.

\section{Nurturing Decolonial Resilience across Space, Time, and Difference}

It is increasingly clear that an existential risk to multiple human and natural systems is posed by anthropogenic climate change. The risks and their potential consequences confirm that continuing to assume that 'nature' is somehow under human governance and management is a dangerous assumption. Equally, assuming that natural or human systems are autonomous or independent at the smaller scales that human governance systems (nations etc.) generally occupy is deeply flawed. Rather, our common human context needs to be recognized in terms of complexly and inescapably coupled human-and-natural systems.

While it is true that many Indigenous knowledge systems have weathered large scale disruption from environmental, social and cosmological processes, their contributions to or fate in light of the existential risks posed by anthropogenic climate change cannot be adequately addressed without contesting the colonial or post-colonial frames that conventionally define and limit the nature, agency and rights of Indigenous peoples. Yuchi scholar Dan Wildcat, from the Muscogee Nation of Oklahoma, put it this way:

[T]hose of us who have been paying attention to our homelands already know ... the world we live in is changing, not the interior spaces and places where the majority of us situated in the midst of the modern industrial and postindustrial societies spend our days and nights, but the world of unbounded landscapes and seascapes that constitute what humankind denominates the natural world. Climate change, however, is only one of many drivers of change. Its effects cannot be isolated from the multiple social, political, economic, and environmental changes confronting present-day indigenous and marginalized communities. Indigenous peoples have long and multi-generational histories of interaction with their environments that include coping with environmental uncertainty, variability, and change. [86] (p. 509)

In other words, the broader risk landscapes, the longer historical and wider geographical scales of contemporary Indigenous experience demand that we pay attention to issues of justice and sustainability in our more-than-human settings in developing the thinking that might allow a more inclusive 'us' to respond to the unnatural disaster that industrialized colonization has visited upon all of our human and non-human companions on the planet. New thinking about climate risk must include the negotiation of respectful modes of belonging-together-in-Country that reshape people-to-people, people-to-environment, and people-to-cosmos relationships in Indigenous domains.

\section{Rescaling the Climate Crisis}

Recognizing this, acknowledging the simultaneously local-to-global and molecular-to-cosmos relevance of Indigenous experience demands a framing (and re-framing) of climate change that shifts across scales. The conventional discourses, which frame climate change in global and near future scale frames, constrain how the challenges are conceptualized and what actions are prioritized. Shifting the scale frames to nurture thinking at the scales of Indigenous self-determination and inter-generational healing allows climate change discourse to bring into focus key issues, such as the geopolitics of Indigenous resilience, vulnerability and adaptation, and reframes the resurgence of Great Power geopolitics.

A wider decolonial project must develop respectful modes of negotiating belonging-togetherin-Country. It must reshape human-to human relations across boundaries of difference and prioritize justice, as well as insisting on state and corporate actors delivering on commitments to reduce the human burden on climate systems. It must acknowledge the continuing presence of Indigenous connections to place, to culture, to history-and to diverse futures. It must nurture modes of becoming 
that reconnect people-to-people, people-to-environment and people-to-cosmos relationships within and beyond Indigenous domains. It needs to recognize that the disruption of these connections underpins the colonial project in order to release resources and energy for the accumulation of obscene wealth and unsustainable burdens on climate systems.

The current disconnection of people from place and environment is marked at multiple scales:

- from the alienation of individuals and disfunction of families and towns, to the melting of permafrost, glaciers and ice sheets;

- from the local wildfires in particular places to the shifting of seasonal patterns of fires so that fire seasons in northern and southern hemispheres now overlap;

- from the myopic failures of local planning systems to secure communities from predictable risks of floods, storms, or fires, to the self-interested myopia of the political classes in major nations while the data drives the recalibration of global insurance systems.

We could think of scale as mediating or moderating all of these relationships. But that is not enough. We certainly need to think differently about scale and the creation and moderation of vulnerability and resilience because these relationships are actually enacted through scale. For example, the scale of Indigenous governance is not something that develops in isolation. Indigenous self-determination and self-governance are always moderated by relationships internal to the dynamics of a particular Indigenous group, and others that reflect the external dynamics that constrain the exercise of governance. In other words, the scale of Indigenous autonomy is always contested and in complex relationships across the scales at which the power and action of formal government administration is constructed and exercised.

Thinking in terms of scale-as-relation $[87,88]$ enables us to think differently about the narratives that reinforce the power of global institutions in climate discourses. It also enables us to rethink the task of decolonizing responses to climate risks facing Indigenous groups.

If one thinks of the dynamics in global climate politics simply in terms of a top-down global hierarchy, understanding what's going on reduces things to either bilateral (global-local) hierarchies or to the enactment of a policy in a local setting. It is easily assumed that the global does (and should) dominate. The paternalistic, colonizing argument says the international system cannot ultimately support Indigenous autonomy, because it will dilute the power to act globally (i.e., to act at the necessary scale) or will split national sovereignty (i.e., disempower the state institutions that are necessary to enforce global actions). That sort of thinking lays the foundations for ongoing deep colonizing. It reproduces the colonial pattern of not holding institutions to account for their impacts across space, time and difference. It allows the present systems of global privilege to continue accumulating and mal-distributing wealth, power, energy and resources from the past and the future-and to masquerade as the only alternative source of solution to the current climate emergency.

\section{Conclusions: Decolonizing for Resilience in Times of Vulnerability}

New thinking about the risk landscapes that confront Indigenous peoples arising from anthropogenic climate change can be built through acknowledgement of and respectful engagement with many Indigenous groups. This will reframe the issues in ways that will challenge many conventions of both thinking and action. It might also allow a shift which recognizes that "current transformations require political actions in numerous places, not just where it has long been assumed political power lies" [83] (p. 47).

The late Deborah Rose wrote powerfully about the force of deep colonizing and the way it corrupts even well-intentioned efforts to transform the impacts of colonization (e.g., [89]). Similarly, Haalboom and Natcher reminded us that our own academic discourses reshape how vulnerability is amplified in unintended ways by the presentation of our evidence and the narratives that people construct in response [2]. These are part of the procedural vulnerability imposed on Indigenous groups. But climate risks render us all more vulnerable. 
Climate risks render Indigenous groups more vulnerable not because of their indigeneity, but because their lives are so often marked by intergenerational legacies and the newly created scars of colonialism. Brazilian educator Paulo Freire [90-92] reminded us long ago that those scars also mark those who might think of ourselves as the beneficiaries of colonialism. While I am deeply conscious of the risk of shallow applications of Freirean pedagogy as a universal solution becoming another form of deep colonizing (see e.g., [93,94]), I also recognize the value of Freirean approaches in providing a locally-referenced reading of the landscapes of risk and colonization. In internalizing conquest, accumulation and wealth as the markers of achievement, our so-called 'modern' societies have been taught to deny and disconnect. Small dissonances and occasional inconveniences in local systems of wellbeing are only now (slowly and unevenly) being reinterpreted as indicators of larger scale problems of systemic crisis. In terms of justice, sustainability and equity, the emperors and their administrators never had any clothes! From the imperial rulers of the 15th Century to the corporate mandarins of big oil, big auto and big trade, the fabric of their power has always been woven from the labor, energy and opportunity of other places, other times and other peoples.

In thinking that the power of colonialism settled their claims of entitlement to power, wealth and privilege, settler-colonial societies discounted the lessons of Indigenous nations who negotiated more sustainable relationships with and connections to place. The colonizers' restless wanderings across temporal, spatial and ecological boundaries allowed the societies they produced to steal from the past, the present and the future. The stories spun to justify their actions were woven from threads of faith, politics and ideology that became central to the modern world's understanding of itself. Those dominant (and dominating) narratives rendered all but impossible to imagine-perhaps intentionally - the alternatives woven in the experiences and practices of Indigenous autonomy, climate justice, the recognition of climate refugees, and the restructuring economic relationships for justice, equity and sustainability across time, space and difference. Indeed, for many people and peoples alienated from any prospect of belonging-in-place and sustainable relationships in coupled human-and-natural-systems, such alternative narratives have become literally unthinkable. Sometimes, in responding to or opposing those dominant narratives, we don't see just how deeply our thinking is captured by their framing of the challenges. We don't realize what has become unthinkable under the influence of the colonizers' self-serving stories.

In working with many Indigenous leaders over my professional life, I have drawn some fundamental conclusions about what lessons for scholars, scientists and academics might be drawn from their resilience, patience and determination:

- Bear witness and document what one witnesses. The importance of witnessing should not be underestimated [95-100]. But it is also imperative that scholars recognize that their privilege as witnesses does not give them free license to interpret and authorize. As Geertz noted, our observations of experience are always already framed by our education and theorizing [101,102], and Bell et al.'s approach of "engaged witnessing" [103] is perhaps close to what I want to suggest is needed.

- Be patient, persistent and humble in leadership. It is important to remember that the fundamental imperatives of many Indigenous struggles are really about the exercise of rights to do the everyday things of their lives-not to perform in the political theatres of law, politics and economics, but to hunt and fish and spend time in their families and Country. While some might be seduced from time to time by the opportunities of money and power, I am humbled by the words of Chief Billy Diamond, who led the negotiation of Canada's first 'modern treaty', the James Bay and Northern Quebec Agreement, who talked about just wanting the opportunity to exercise the rights that the treaty recognized, and not having to return to the negotiating table over and over again in order to hold governments accountable for implementing the treaty properly [104].

- Offer interpretation, understanding and explanation not only to the already rich and powerful, but importantly also to the people whose lives are affected by change. It is important that information and explanation is accessible to others and based on the available evidence, and this requires 
acknowledgement, engagement and discussion (education), not just the assertion of expertise by leaders and advisors-humility is required, as is the ability, willingness and opportunity to listen. Recognize that what constitutes evidence in different realms and settings will vary (sometimes unpredictably) over time and between circumstances.

- Connection and belonging are important, but in new circumstances we need to get the scales (spatial, temporal, ecological and social) right, rather than assume that things remain the same. Indigenous cultures are contemporary and dynamic - they are not some sort of window on the human past, but the context of Indigenous peoples continuing experience-the past-present-future continuous that is the foundation of The Dreaming, which informs Australian Indigenous ontology.

- Take responsibility - there is no shortage of mythical, political and scientific narratives about the need for people to understand that knowledge has consequences and there is a responsibility attached to knowledge. The failure to take responsibility for knowledge, insisting on the construction of ignorance, and the denial of causal and ethical relationships between actions, events and knowledge- these things are warned against in multiple human narratives, from those that shape relations in the ancient jurisdictions of First Nations to the drivers of contemporary research ethics.

- Consider what sort of Ancestor you want to be-at the conference on which this special issue of Sustainability was imagined into life, Professor Gregory Cajete articulated this question in ways that profoundly challenged many aspects of my thinking and being. The Ancestors of Indigenous nations are often eulogized in ways that risk forgetting that the Ancestors were people like ourselves, who were acting with courage, humility and integrity to connect possible futures to their own pasts and presents. They became the sort of revered Ancestors who made it possible for us to be and for our coupled human-and-natural systems to continue becoming, but they were actors who were responding to challenges of survival, justice and integrity, just like us.

- Act-silence and inaction cannot be justified. While there are many perspectives on what constitutes just action (and what action is appropriate in various settings), the cycles of understanding-acting-and-reflecting that are embedded in the ethical advice to human communities encoded in sacred texts, mythical narratives and research methodologies are clear that understanding brings a responsibility to act, and that actors are to be held accountable.

Funding: This research received no external funding. My attendance at the international forum 'Climate Change, Indigenous Resilience and Local Knowledge Systems: Cross-time and Cross-boundary Perspectives', held in Taipei, Taiwan on December 13-15 2019, was supported by funding from the Research Institute for the Humanities and Social Sciences, Ministry of Science and Technology.

Acknowledgments: I would like to acknowledge the organizing committee of the international forum. Their support for my participation in the conference provided the impetus to finalize this paper. I would particularly like to thank Hue-Min Tsai, Sue-Ching Jou, Jolan Hsieh and Yuju Wang.

Conflicts of Interest: The author declares no conflict of interest.

\section{References}

1. Hsu, M.; Howitt, R.; Chi, C.-C. The idea of 'Country': Reframing post-disaster recovery in Indigenous Taiwan settings. Asia Pac. Viewp. 2014, 55, 370-380. [CrossRef]

2. Haalboom, B.J.; Natcher, D.C. The Power and Peril of 'Vulnerability': Lending a Cautious Eye to Community Labels in Climate Change Research. Arctic 2012, 65, 319-327. [CrossRef]

3. Reid, J. "We the resilient": Colonizing indigeneity in the era of trump. Resilience 2019, 7, 255-270. [CrossRef]

4. Lindroth, M.; Sinevaara-Niskanen, H. Colonialism invigorated? The manufacture of resilient indigeneity. Resilience 2019, 7, 240-254. [CrossRef]

5. Ostrom, E. A diagnostic approach for going beyond panaceas. Proc. Natl. Acad. Sci. USA 2007, 104, 15181-15187. [CrossRef]

6. Johnson, J.; Howitt, R.; Cajete, G.; Berkes, F.; Louis, R.; Kliskey, A. Weaving Indigenous and sustainability sciences to diversify our methods. Sustain. Sci 2016, 11, 1-11. [CrossRef] 
7. Howitt, R. Knowing/Doing. In A Companion to Social Geography; Del Casino, V.J., Jr., Thomas, M.E., Cloke, P., Panelli, R., Eds.; Wiley-Blackwell: Chichester, UK, 2011; pp. 131-145.

8. Veland, S. Indigenous Contexts of Climate and Change: Narrating Local Realities within Global Discourses; Macquarie University: Sydney, Australia, 2011.

9. Veland, S.; Howitt, R.; Dominey-Howes, D.; Thomalla, F.; Houston, D.D. Procedural vulnerability: Understanding environmental change in a remote indigenous community. Glob. Environ. Chang. 2013, 23, 314-326. [CrossRef]

10. Hsu, M. Expert-Centred Discourses and Indigenous Autonomy in Post-Disaster Settings: Insights from Wutai Rukai Experiences in Taiwan; Thesis Comnpleted as Cotutelle with National Dong Hwa University, Taiwan; Macquarie University: Sydney, Australia, 2016.

11. Hsu, M.; Howitt, R.; Miller, F. Procedural Vulnerability and Institutional Capacity Deficits in Post-Disaster Recovery and Reconstruction: Insights from Wutai Rukai Experiences of Typhoon Morakot. Hum. Organ. 2015, 74, 308-318. [CrossRef]

12. Hsu, M.; Okada, T.; Mori, S.; Howitt, R. Resettling, disconnecting or displacing? Attending to local sociality, culture and history in disaster settings. Asia Pac. Viewp. 2019, 60, 163-174. [CrossRef]

13. Howitt, R.; Havnen, O.; Veland, S. Natural and Unnatural Disasters: Responding with Respect for Indigenous Rights and Knowledges. Geogr. Res. 2012, 50, 47-59. [CrossRef]

14. Walker, B. Murray-Darling Basin Royal Commission Report; Government of South Australia: Adelaide, Australia, 2019.

15. Australian Academy of Science. Investigation of the Causes of Mass Fish Kills in the Menindee Region of NSW over the Summer of 2018-2019; Australian Academy of Science: Canberra, Australian, 2019; Available online: http://www.science.org.au/fish-kills-report (accessed on 11 November 2019).

16. Jackson, S.; Head, L. Australia's mass fish kills as a crisis of modern water: Understanding hydrosocial change in the Murray-Darling Basin. Geoforum 2020, 109, 44-56. [CrossRef]

17. Mesenger, A. Kangawalla fire: Tragedy as firefighters battling Kangawalla fire near Glen Innes discover body in car. Glen Innes Examiner. 9 November 2019. Available online: https://www.canberratimes.com.au/ story/6483394/two-dead-nine-unaccounted-for-as-fire-destroys-nsw-town/ (accessed on 29 June 2020).

18. Sparks, C. We've been in bushfire hell in Glen Innes and the scientists knew it was coming. The Guardian (Online). 11 November 2019. Available online: https:/www.theguardian.com/commentisfree/2019/nov/ 11/weve-been-in-bushfire-hell-in-glen-innes-and-the-scientists-knew-it-was-coming (accessed on 29 June 2020).

19. Flanagan, R. Australia is committing climate suicide. New York Times. 3 January 2020. Available online: https://www.nytimes.com/2020/01/03/opinion/australia-fires-climate-change.html (accessed on 8 June 2020).

20. Head, L. Transformative change requires resisting a new normal. Nat. Clim. Chang. 2020, 10, $173-174$. [CrossRef]

21. Newman, S. In Their Own Words: The Hidden Impact of Prolonged Drought on Children and Young People; UNICEF Australia: Sydney, Australia, 2019.

22. Vousdoukas, M.I.; Ranasinghe, R.; Mentaschi, L.; Plomaritis, T.A.; Athanasiou, P.; Luijendijk, A.; Feyen, L. Sandy coastlines under threat of erosion. Nat. Clim. Chang. 2020, 10, 260-263. [CrossRef]

23. BBC World News Australia: Extreme weather in pictures. Available online: https://www.bbc.com/news/inpictures-51175698 (accessed on 8 June 2020).

24. Dominey-Howes, D. Climate change is bringing a new world of bushfires. The Conversation (Online Journal). Available online: http://theconversation.edu.au/ (accessed on 10 September 2019).

25. Mullins, G. This is not normal: what's different about the NSW mega fires. Sydney Morning Herald. 11 November 2019. Available online: https://www.smh.com.au/national/this-is-not-normal-what-s-differentabout-the-nsw-mega-fires-20191110-p5395e.html (accessed on 29 June 2020).

26. Hartwig, D.L.; Jackson, S.; Osborne, N. Recognition of Barkandji Water Rights in Australian Settler-Colonial Water Regimes. Resources 2018, 7, 16. [CrossRef]

27. Weir, J.K. Connectivity. Aust. Humanit. Rev. 2008, 45, 153-164.

28. Gibbs, L.M. Just add water: Colonisation, water governance, and the Australian inland. Environ. Plan. 2009, 41, 2964-2983. [CrossRef]

29. Alston, M.; Kent, J. Social Impacts of Drought: A Report to NSW Agriculture; Centre for Rural Social Research, Chanrles Sturt University: Wagga, Australia, 2004. 
30. Pulido, L. Geographies of race and ethnicity III: Settler colonialism and nonnative people of color. Prog. Hum. Geogr. 2018, 42, 309-318. [CrossRef]

31. Head, L. Second Nature: The History and Implications of Australia as Aboriginal Landscape; Syracuse University Press: Syracuse, Italy, 2000.

32. Langton, M. Art, wilderness and terra nullius. In Perspectives on Indigenous Peoples Management of Environment Resources, Proceedings of the Ecopolitics IX, Northern Territory University, Darwin, 1-3 September 1995; Sultan, R., Josif, P., Mackinolty, C., Mackinolty, J., Eds.; Northern Land Council: Darwin, Australia, 1996; pp. 11-24.

33. Williams, S. Rendering the Untimely Event of Disaster Ever Present. Landsc. Rev. 2012, 14, 86-96.

34. Clendinnen, I. True Stories: Boyer Lectures 1999; ABC Books: Sydney, Australia, 1999.

35. Agius, P.; Davies, J.; Howitt, R.; Jarvis, S.; Williams, R. Comprehensive Native Title Negotiations in South Australia. In Honour Among Nations? Treaties and Agreements with Indigenous People; Langton, M., Teehan, M., Palmer, L., Shain, K.K., Eds.; Melbourne University Press: Melbourne, Australia, 2004; pp. 203-219.

36. Howitt, R. Unsettling the taken (-for-granted). Prog. Hum. Geogr. 2020, 44, 193-215. [CrossRef]

37. Wolfe, P. The Settler Complex: An Introduction. Am. Indian Cult. Res. J. 2013, 37, 1-22. [CrossRef]

38. Pascoe, B. Dark Emu: Black Seeds Agriculture or Accident; Magabala Books: Broome, Australia, 2018.

39. Gammage, B. The Biggest Estate on Earth: How Aborigines Made Australia/Bill Gammage; Allen \& Unwin: Crows Nest, Australia, 2011.

40. Clarkson, C.; Jacobs, Z.; Marwick, B.; Fullagar, R.; Wallis, L.; Smith, M.; Roberts, R.G.; Hayes, E.; Lowe, K.; Carah, X.; et al. Human occupation of northern Australia by 65,000 years ago. Nature 2017, 547, 306. [CrossRef] [PubMed]

41. Thunberg, G. 'You Did Not Act in Time': Greta Thunberg's Full Speech to MPs. The Guardian. 23 April 2019. Available online: https:/www.theguardian.com/environment/2019/apr/23/greta-thunberg-full-speech-tomps-you-did-not-act-in-time (accessed on 8 June 2020).

42. Thunberg, G. Speech to United Nations General Assembly Climate Action Summit. Available online: https://www.rev.com/blog/greta-thunberg-un-climate-action-summit-speech-transcript-2019-howdare-you (accessed on 8 June 2020).

43. Howitt, R. Sustainable indigenous futures in remote Indigenous areas: Relationships, processes and failed state approaches. GeoJournal 2012, 77, 817-828. [CrossRef]

44. Dalby, S. Geoengineering: The Next Era of Geopolitics? Geogr. Compass 2015, 9, 190-201. [CrossRef]

45. Steffen, W.; Persson, Å.; Deutsch, L.; Zalasiewicz, J.; Williams, M.; Richardson, K.; Crumley, C.; Crutzen, P.; Folke, C.; Gordon, L.; et al. The Anthropocene: From Global Change to Planetary Stewardship. Ambio 2011, 40, 739-761. [CrossRef]

46. Eckersley, R. Climate change negotiations at the crossroads. Glob. Chang. Peace Secur. 2005, 17, 7-10. [CrossRef]

47. Liverman, D. Conventions of climate change: Constructions of danger and the dispossession of the atmosphere. J. Hist. Geogr. 2009, 35, 279-296. [CrossRef]

48. Pelling, M.; Dill, K. Disaster politics: Tipping points for change in the adaptation of sociopolitical regimes. Prog. Hum. Geogr. 2010, 34, 21-37. [CrossRef]

49. Marston, S.A.; Jones, J.P.; Woodward, K. Human Geography Without Scale. Trans. Inst. Br. Geogr. 2005, 30, 416-432. [CrossRef]

50. Head, L. Contingencies of the Anthropocene: Lessons from the 'Neolithic'. Anthr. Rev. 2014, 1, 113-125. [CrossRef]

51. Stoffle, R.; Arnold, R.; Van Vlack, K. Facing the Unimaginable: Hopi and Southern Paiute Respond to Massive Risk Events. Appl. Anthropol. 2015, 35, 13-22.

52. Heidegger, M. Being and Time: A Translation of Sein und Zeit/Martin Heidegger Translated by Joan Stambaugh; State University of New York Press: Albany, NY, USA, 1996.

53. Nancy, J.-L. Being Singular Plural; Stanford University Press: Stanford, CA, USA, 2000.

54. Larsen, S.C.; Johnson, J.T. Being Together in Place: Indigenous Co-Existence in a More than Human World; University of Minnesota Press: Minneapolis, MN, USA, 2017.

55. Howitt, R.; Doohan, K.; Suchet-Pearson, S.; Cross, S.; Lawrence, R.; Lunkapis, G.J.; Muller, S.; Prout, S.; Veland, S. Intercultural capacity deficits: Contested geographies of coexistence in natural resource management. Asia Pac. Viewp. 2013, 54, 126-140. [CrossRef] 
56. Howitt, R.; Suchet-Pearson, S. Ontological Pluralism in Contested Cultural Landscapes. In Handbook of Cultural Geography; Anderson, K., Domosh, M., Pile, S., Thrift, N., Eds.; Sage: London, UK, 2003; pp. 557-569.

57. Howitt, R.; Suchet-Pearson, S. Rethinking the Building Blocks: Ontological Pluralism and the Idea of 'Management'. Geogr. Ann. Ser. B Hum. Geogr. 2006, 88, 323-335. [CrossRef]

58. Stoffle, R.; Arnold, R. Facing the Unimaginable: The Limits of Resilience and The Risk Society. In Proceedings of the First International Sociology Association Forum on 'Sociology and Public Debate', Barcelona, Spain, 5-8 September 2008.

59. Stoffle, R.; Minnis, J. Resilience at risk: Epistemological and social construction barriers to risk communication. J. Risk Res. 2008, 11, 55-68. [CrossRef]

60. Stoffle, R.; Rogers, G.; Grayman, F.; Benson, G.B.; Van Vlack, K.; Medwied-Savage, J. Timescapes in conflict: Cumulative impacts on a solar calendar. Impact Assess. Proj. Apprais. 2008, 26, 209-218. [CrossRef]

61. Stoffle, R.W.; Arnold, R. Confronting the Angry Rock: American Indian's Situated Risks from Radioactivity. Ethnos 2003, 68, 1-20. [CrossRef]

62. Danowski, D.; Castro, E.V.D. The Ends of the World; Polity Press: Cambridge, UK, 2017.

63. Gaillard, J.C. Vulnerability, capacity and resilience: Perspectives for climate and development policy. J. Int. Dev. 2010, 22, 218-232. [CrossRef]

64. Gaillard, J.C.; Mercer, J. From knowledge to action: Bridging gaps in disaster risk reduction. Prog. Hum. Geogr. 2013, 37, 93-114. [CrossRef]

65. Hsu, M. Lost, found and troubled in translation: Reconsidering imagined Indigenous "communities" in postdisaster Taiwan settings. Altern. Int. J. Indig. Peoples 2016, 12, 71-85. [CrossRef]

66. Shaw, R. Post Disaster Recovery: Issues and Challenges. In Disaster Recovery; Shaw, R., Ed.; Springer: Tokyo, Japan, 2014; pp. 1-13.

67. Thomalla, F.; Downing, T.; Spanger-Siegfried, E.; Han, G.; Rockström, J. Reducing hazard vulnerability: Towards a common approach between disaster risk reduction and climate adaptation. Disasters 2006, 30, 39-48. [CrossRef]

68. Miller, F.; Osbahr, H.; Boyd, E.; Thomalla, F.; Bharwan, S.; Ziervogel, G.; Walker, B.; Birkmann, J.; Leeuw, S.V.D.; Rockström, J.; et al. Resilience and Vulnerability: Complementary or Conflicting Concepts? Ecol. Soc. 2010, 15, 11. Available online: http://www.ecologyandsociety.org/vol15/iss3/art11/ (accessed on 8 June 2020). [CrossRef]

69. Komiyama, H.; Takeuchi, K. Sustainability science: Building a new discipline. Sustain. Sci. 2006, 1, 1-6. [CrossRef]

70. Escobar, A. Imagining a post-development era? critical thought, development and social movements. Soc. Text. 1992, 31/32, 20-56. [CrossRef]

71. Rapley, J. Development studies and the post-development critique. Prog. Dev. Stud. 2004, 4, 350-354. [CrossRef]

72. Larsen, S.C.; Johnson, J.T. In between worlds: Place, experience, and research in Indigenous geography. J. Cult. Geogr. 2012, 29, 1-13. [CrossRef]

73. Whyte, K.P. Indigeneity in Geoengineering Discourses: Some Considerations. Ethics Policy Environ. 2019, 1-19. [CrossRef]

74. Hughes, T.P.; Carpenter, S.; Rockström, J.; Scheffer, M.; Walker, B. Multiscale regime shifts and planetary boundaries. Trends Ecol. Evol. 2013, 28, 389-395. [CrossRef] [PubMed]

75. Hughes, T.P.; Linares, C.; Dakos, V.; van de Leemput, I.A.; van Nes, E.H. Living dangerously on borrowed time during slow, unrecognized regime shifts. Trends Ecol. Evol. 2013, 28, 149-155. [CrossRef] [PubMed]

76. Veland, S.; Lynch, A.H. Scaling the Anthropocene: How the stories we tell matter. Geoforum 2016, 72, 1-5. [CrossRef]

77. Liverman, D. Who Governs, at What Scale and at What Price? Geography, Environmental Governance, and the Commodification of Nature. Ann. Assoc. Am. Geogr. 2004, 94, 734-738.

78. Whyte, K. Too late for indigenous climate justice: Ecological and relational tipping points. Wiley Interdiscip. Rev. Clim. Chang. 2019. [CrossRef]

79. Hamilton, C. The Anthropocene as rupture. Anthr. Rev. 2016, 3, 93-106. [CrossRef]

80. Brunn, S.D. Engineering Earth: The Impacts of Megaengineering Projects; Springer: Dordrecht, The Netherlands, 2011. 
81. Galaz, V.; Biermann, F.; Crona, B.; Loorbach, D.; Folke, C.; Olsson, P.; Nilsson, M.; Allouche, J.; Persson, Å.; Reischl, G. 'Planetary boundaries' —exploring the challenges for global environmental governance. Curr. Opin. Environ. Sustain. 2012, 4, 80-87. [CrossRef]

82. Walker, B.; Barrett, S.; Polasky, S.; Galaz, V.; Folke, C.; Engström, G.; Ackerman, F.; Arrow, K.; Carpenter, S.; Chopra, K.; et al. Looming Global-Scale Failures and Missing Institutions. Science 2009, 325, 1345-1346. [CrossRef] [PubMed]

83. Dalby, S. Framing the Anthropocene: The good, the bad and the ugly. Anthr. Rev. 2016, 3, 33-51. [CrossRef]

84. Atkinson, J. Trauma Trails, Recreating Song Lines: The Transgenerational Effects of Trauma in Indigenous Australia/Judy Atkinson; Spinifex Press: North Melbourne, Australia, 2002.

85. Berger, T.R. A Long and Terrible Shadow: White Values, Native Rights in the Americas; Douglas \& McIntyre and University of Washington Press: Vancouver, WA, USA; Seattle, WA, USA, 1991; p. 183.

86. Wildcat, D. Introduction: Climate change and indigenous peoples of the USA. Clim. Chang. 2013, 120, 509-515. [CrossRef]

87. Howitt, R. Scale as relation: Musical metaphors of geographical scale. Area 1998, 30, 49-58. [CrossRef]

88. Howitt, R. 'A World in a Grain of Sand': Towards a reconceptualization of geographical scale. Aust. Geogr. 1993, 24, 33-44. [CrossRef]

89. Rose, D.B. Indigenous Ecology and an Ethic of Hope. In Global Ethics and Environment; Routledge: London, UK, 1999; pp. 175-187.

90. Freire, P. Pedagogy of the Oppressed; Penguin: Harmondsworth, UK, 1972; p. 153.

91. Freire, P. Pedagogy of the Oppressed, 30th Anniversary ed.; Bloomsbury: New York, NY, USA, 2000.

92. Freire, P. Pedagogy of Hope: Reliving Pedagogy of the Oppressed; Bloomsbury Academic: London, UK; New York, NY, USA, 2014.

93. Blackburn, J. Understanding Paulo Freire: Reflections on the origins, concepts, and possible pitfalls of his educational approach. Community Dev. J. 2000, 35, 3-15. [CrossRef]

94. Célèste Kee, J.; Carr-Chellman, D.J.; Paulo, F. Critical Literacy, and Indigenous Resistance. Educ. Stud. 2019, 55, 89-103. [CrossRef]

95. Deranty, J.-P. Witnessing the Inhuman: Agamben or Merleau-Ponty. South Atl. Q. 2008, 107, $165-186$. [CrossRef]

96. Goodman, N.R. The Power of Witnessing. In The Power of Witnessing: Reflections, Reverberations, and Traces of the Holocaust; Goodman, N.R., Meyers, M.B., Eds.; Routledge: New York, NY, USA; London, UK, 2012; pp. 3-26.

97. Houston, D. Environmental Justice Storytelling: Angels and Isotopes at Yucca Mountain, Nevada. Antipode 2013, 45, 417-435. [CrossRef]

98. Hunt, S. Researching within relations of violence: Witnessing as methodology. In Indigenous Research: Theories, Practices, and Relationships; McGregor, D., Restoule, J.-P., Johnston, R., Eds.; Canadian Scholars: Toronto, ON, Canada; Vancouver, BC, Canada, 2018; pp. 282-295.

99. Oliver, K. Beyond Recognition: Witnessing Ethics. Philos. Today 2000, 44, 31-43. [CrossRef]

100. Till, K.E. Wounded cities: Memory-work and a place-based ethics of care. Political Geogr. 2012, 31, 3-14. [CrossRef]

101. Geertz, C. The Interpretation of Cultures; Basic Books: New York, NY, USA, 1973.

102. Geertz, C. Blurred Genres. Am. Sch. 1980, 49, 165-179.

103. Bell, S.J.; Instone, L.; Mee, K.J. Engaged witnessing: Researching with the more-than-human. Area 2017, 50, 136-144. [CrossRef]

104. Diamond, B. Villages of the Dammed. Arct. Circ. 1990, 1, $24-34$.

(C) 2020 by the author. Licensee MDPI, Basel, Switzerland. This article is an open access article distributed under the terms and conditions of the Creative Commons Attribution (CC BY) license (http://creativecommons.org/licenses/by/4.0/). 